\title{
Optimization of steel buildings by changing structural system and using lightweight materials
}

\author{
H. Babaalia ${ }^{*}$, F. Omidinasab ${ }^{b}$, A. Dalvand ${ }^{c}$ and Sh. Akhondi ${ }^{d}$ \\ ${ }^{a}$ Assistant Professor, Department of Civil Engineering, Khorramabad Branch, Islamic Azad University, Khorramabad, Iran \\ ${ }^{b}$ Assistant Professor, Department of Civil Engineering, Lorestan University, Khorramabad, Iran \\ ${ }^{c}$ Masters Graduated in Structural engineering, Lorestan University, Khorramabad, Iran \\ ${ }^{d}$ Politecnico di-Milano, Department of Mechanical Engineering, Milan, Italy
}

\begin{tabular}{l}
\hline A R T I C L EI N F O \\
\hline Article history: \\
Received March, 2018 \\
Accepted 25 June 2019 \\
Available online \\
25 June 2019 \\
\hline Keywords: \\
Optimization \\
Steel buildings \\
Lightweight
\end{tabular}

\begin{abstract}
A B S T R A C T
Inappropriate use of gravity and lateral load-bearing system and the use of inappropriate materials may increase in weight of the structure. Thus, we see an increase in gravity and lateral forces and consequently the beam and column dimensions of elements increase. In this paper, by taking several samples of buildings with steel frames and number of different floors and use of different materials as well as various gravity and lateral load-bearing systems this issue was investigated. It was observed that by the use of steel bracing system in both directions of buildings with steel frames; each different load-bearing results in minimum weight loading per unit surface of the skeleton of structure. It was also observed more effect of lightweight construction by increasing the number of floors for all lateral load-bearing systems. Effects of lightweight construction for different lateral load-bearing systems was investigated and we observed that the effects of lightweight construction commonly used for buildings with moment frame system in both directions were more than the rest of the buildings with lateral load-bearing systems.
\end{abstract}

\section{Introduction}

The biggest anxiety of all the seismic countries in the world after the earthquake is the loss of life and property resulting from this natural phenomenon. Iran is not an exception among them and is one of the most vulnerable earthquake-prone countries in the world with little reflection on how to design structures to significantly reduce their damaging effects. Building of appropriate structures (e.g. high energy dissipation capacity) at earthquake-prone areas can create ideal conditions for protecting us from the earthquake. Lightweight constructions and weight reduction of buildings directly reduce the force of the earthquake inflicted on the structure. Thus, by the use of lightweight materials, design structures will lead to technical and economic needs. As a result, building construction by using the modern methods, in addition to reducing the weight of the structure and earthquake can assist in the economic issues of the projects. Increasing the population and some limitations (such as lack of suitable locations for construction and materials) results in the necessity of using high buildings with smaller divided interiors. Inappropriate use of gravity and lateral load-bearing systems and the use of inappropriate materials cause an increase in the weight of structure and consequently results in increasing the dimensions of beam and column elements. This issue is investigated and examined in this paper by choosing several steel frame

* Corresponding author.

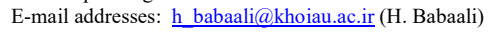


building with a number of different floors and the use of different materials as well as gravity and lateral load-bearing elements.

There are many studies for designing and analyzing the buildings subjected to dynamic or seismic loads (Mohammed et al., 2017; Dehghani et al., 2015; Šipoš et al., 2015; Sazedj et al., 2017; Bothara et al., 2018; Priestley, 1986; Priestley \& Seible, 1995; Duggal, 2007; Park, 2009; Uang, 1991; Ellingwood, 2001; Azizi-Bondarabadi et al., 2016). Most practical research works conducted for evaluating the effect of reduced weight on the optimization of non- structural materials have suggested decreasing the amount of steel and armature consumption and reduce dimensions of beams and structural columns. In addition, modern lightweight materials are considered more appropriate from economical point of view and vulnerability to earthquakes. In a comparison which was done on the two concrete buildings by comparing the maximum shift criterion at a level of risk and by changing non-structural materials it was investigated that the light structures have higher flexibility and lower displacement (Hamidi Nezhad \& Rezaei, 2010). Thus without changing the structural performance it is possible to reduce the weight of structures in order to be more flexible and add to the structure floors as the same amount of weight reduction. Seyed Kazemi et al. (2010) examined the steel buildings with different heights, studied the effects of weight loss of materials as well as the type of structural systems and determined that the use of nonlinear methods in the design of steel structures can be effective in weight loss of skeletons. Khatami and Tavoosi Tafreshi (2010) studied the type of lateral load-bearing system on steel structures with different number of floors on weight loss and skeleton of structures and have investigated that using a simple frame in one direction and moment frame in the other direction reduces skeleton weight by 20 percent compared to the system with moment frame. Gorman et al. (1988) by construction of prefabricated walls of plasterboard succeeded in considerably reducing the weight of walls for each square meter and make filling materials with less weight than brick pressure and siporex. Also Naghipour and Hatem (2004) evaluated how to have more economic structures with reduced weight. They studied three types of roof structures with a variety of filler walls and structural systems and achieved the amount of reduction of steel percent by reducing the weight of the ceiling per each square meter. Rahimi Asl et al. (2011) considered the effects of architectural principles such as the plan shape, plan size, arrangement of blocks together on one site, the design of interior spaces, type and material of the facade in weight reduction and provided strategies for optimal use of the mentioned issues reducing the weight of the buildings. In this paper, the combined effects of reducing weight of wall materials and blades also changing in lateral and gravity load-bearing system of the steel building with a number of different floors was investigated. In this regard to evaluate and compare the combined effects of these two parameters on weight loss of skeleton of buildings per each square meter, the floor area is discussed. Also in this article we considere the buildings with a maximum ten-floor that have the highest percentage among all buildings. For different types of buildings on matter of number of floors like short-rise, mid-rise and high-rise buildings in steel buildings the best load-bearing systems in terms of weight loss of consumable materials is recommended.

\section{Loading assumptions}

The first step in the construction of any building is drawing of suitable architectural plans. Inappropriate architectural plans can include an irregularity in plan or height of the structure. This phenomenon leads to complexity in the behavior of structures and thus difficulty in analysis and design of structures. In this paper for better and more logical comparison of results and the use of a type of analysis for all the buildings, a regular architectural plan is intended. The mentioned plan has three spans with a length of 4, 4.85 and 4.99 meters in the x-direction and three spans with the length of $4.5,2.7$ and 5 meters in the Y-direction.

For loading of buildings in terms of the sixth issue of national Iranian regulations of construction and for seismic design of buildings, the Fourth Edition of 2800 regulations is used (Iranian National Building 
Code, 2013). The type of roof coverings in all buildings and blocks is considered. The surrounding walls and divider walls (blades) once for brick and once again for 3D PANEL and of drywall are intended. Calculations of mass per unit of area of the building components are presented in Tables 1 to 9:

Table 1. The weight per unit of area for ceiling of the building floors

\begin{tabular}{|c|c|c|c|}
\hline Element type & $\begin{array}{c}\text { Weight per unit area } \\
\left(\mathrm{kg} / \mathrm{m}^{2}\right)\end{array}$ & Thickness (m) & $\begin{array}{l}\text { Weight per unit volume } \\
\left(\mathrm{kg} / \mathrm{m}^{3}\right)\end{array}$ \\
\hline Ceramic & 21 & 0.01 & 2100 \\
\hline Cement sand mortar & 63 & 0.03 & 2100 \\
\hline Light concrete with Pumice & 65 & 0.05 & 1300 \\
\hline Concrete Structural & 125 & 0.05 & 2500 \\
\hline Polystyrene blocks & 2 & - & - \\
\hline Piles Weight & 100 & - & 2500 \\
\hline Element type & 376 & & \\
\hline
\end{tabular}

Table 2. The weight per unit of area for ceiling of the building floors

\begin{tabular}{lccc}
\hline \multicolumn{1}{c}{ Element type } & $\begin{array}{c}\text { Mass per unit area } \\
\left(\mathrm{kg} / \mathrm{m}^{2}\right)\end{array}$ & Thickness $(\mathrm{m})$ & $\begin{array}{c}\text { Weight per unit volume } \\
\left(\mathrm{kg} / \mathrm{m}^{3}\right)\end{array}$ \\
\hline Ceramic & 48 & 0.02 & 2400 \\
Cement sand mortar & 63 & 0.03 & 2100 \\
Concrete with Pumice & 130 & 0.1 & 1300 \\
Bituminous waterproofing & 15 & - & - \\
The thickness of the concrete structure & 125 & 0.05 & 2500 \\
Polystyrene blocks & 2 & - & - \\
Piles weight & 100 & - & 2500 \\
\hline Total & 483 & &
\end{tabular}

Table 3. Calculation of the weight per unit of area surrounding the facade walls (walls with brick materials)

\begin{tabular}{lccc} 
Element type & $\begin{array}{c}\text { Weight per unit volume } \\
\left(\mathrm{kg} / \mathrm{m}^{2}\right)\end{array}$ & Thickness $(\mathrm{m})$ & $\begin{array}{c}\text { Mass per unit area } \\
\left(\mathrm{kg} / \mathrm{m}^{3}\right)\end{array}$ \\
\hline Plaster & 13 & 0.01 & 1300 \\
Plaster and soil & 32 & 0.02 & 1600 \\
Brickwork with caved brick & 170 & 0.2 & 850 \\
cement sand mortar & 63 & 0.03 & 2200 \\
Travertine & 56 & 0.02 & 2800 \\
\hline Total & 334 & &
\end{tabular}

Table 4. Calculation of the weight per unit of area without the facade surrounding walls (walls with brick materials)

\begin{tabular}{llll}
\hline Element type & $\begin{array}{l}\text { Weight per unit volume } \\
\left(\mathrm{kg} / \mathrm{m}^{2}\right)\end{array}$ & Thickness & $\begin{array}{l}\text { Mass per unit area } \\
\left(\mathrm{kg} / \mathrm{m}^{3}\right)\end{array}$ \\
\hline Plaster & 13 & 0.01 & 1300 \\
Plaster and soil & 32 & 0.02 & 1600 \\
Brickwork with caved brick & 170 & 0.2 & 850 \\
cement sand mortar & 63 & 0.03 & 2100 \\
\hline Total & 278 & & \\
\hline
\end{tabular}

Table 5. Calculation of linear load of surrounding walls (walls with brick materials)

\begin{tabular}{ccccc}
\hline Floor & Height $(\mathrm{m})$ & $\begin{array}{c}\text { The walls of the facade } \\
\text { with openings } \mathrm{kg} / \mathrm{m}\end{array}$ & $\begin{array}{c}\text { The walls of the facade } \\
\text { without opening }\end{array}$ & The walls without facade \\
\hline First, second, third & 2.9 & $335 \times 2.9 \times 0.7=680$ & $335 \times 2.9 \cong 972$ & $278 \times 2.9 \cong 807$ \\
Shelter & 1 & 300 & 300 & 300 \\
\hline
\end{tabular}

Table 6. Calculation of the weight per unit area of the blades (walls with brick materials)

\begin{tabular}{cccc}
\hline Element type & $\begin{array}{c}\text { Weight per unit volume } \\
\left(\mathrm{kg} / \mathrm{m}^{3}\right)\end{array}$ & Thickness $(\mathrm{m})$ & $\begin{array}{c}\text { Mass per unit area } \\
\left(\mathrm{kg} / \mathrm{m}^{2}\right)\end{array}$ \\
\hline Plaster & 1300 & 0.01 & 26 \\
Plaster and soil & 1600 & 0.02 & 64 \\
$\begin{array}{c}\text { Brickwork with caved bricks and } \\
\text { cement sand mortar }\end{array}$ & 850 & 0.07 & 60 \\
\hline Total & & & 150
\end{tabular}

Table 7. Calculation of the weight per unit of area of surrounding walls with facade (3D PANEL walls) 


\begin{tabular}{|c|c|c|c|c|}
\hline Element type & $\begin{array}{c}\text { Mass per unit area } \\
\left(\mathrm{kg} / \mathrm{m}^{\mathbf{3}}\right)\end{array}$ & Thickness(m) & $\begin{array}{c}\text { Number of } \\
\text { Layers }\end{array}$ & $\begin{array}{c}\text { Weight per unit volume } \\
\left(\boldsymbol{k} \boldsymbol{g} / \boldsymbol{m}^{\mathbf{2}}\right)\end{array}$ \\
\hline Plaster & 1300 & 0.01 & 1 & 13 \\
\hline Cement sand mortar & 2100 & 0.03 & 2 & 126 \\
\hline Polystyrene & 15 & 0.15 & 1 & 2.25 \\
\hline Rebar Networks ( $\varnothing 4 @ 10 \mathrm{~cm}$ ) & 7800 & - & 1 & 3.95 \\
\hline Travertine & 2800 & 0.02 & 1 & 56 \\
\hline Total & & & & $\cong 202$ \\
\hline
\end{tabular}

Table 8. Calculation of weight per unit of area of the surrounding walls without facade (3D PANEL walls)

\begin{tabular}{|c|c|c|c|c|}
\hline Load name & $\begin{array}{l}\text { Mass per unit area } \\
\left(\boldsymbol{k g} / \boldsymbol{m}^{\mathbf{3}}\right)\end{array}$ & $\begin{array}{c}\text { Thickness } \\
(\mathrm{m})\end{array}$ & $\begin{array}{c}\text { Number of } \\
\text { Layers }\end{array}$ & $\begin{array}{l}\text { Weight per unit volume } \\
\left(\mathrm{kg} / \mathrm{m}^{2}\right)\end{array}$ \\
\hline Plaster & 1300 & 0.01 & 1 & 13 \\
\hline cement sand mortar & 2100 & 0.03 & 2 & 126 \\
\hline Polystyrene & 15 & 0.15 & 1 & 2.25 \\
\hline Networks rebar $(\varnothing 4 @ 10 \mathrm{~cm})$ & 7800 & - & 1 & 3.95 \\
\hline
\end{tabular}

Table 9. Calculation of linear load of the surrounding walls (3D PANEL walls)

\begin{tabular}{ccccc}
\hline floor & $\begin{array}{c}\text { height } \\
(\boldsymbol{m})\end{array}$ & $\begin{array}{c}\text { The walls of the facade } \\
\text { with openings } \\
(\mathbf{k g} / \mathbf{m})\end{array}$ & $\begin{array}{c}\text { The walls of the facade } \\
\text { without opening } \\
(\mathbf{k g} / \mathbf{m})\end{array}$ & $\begin{array}{c}\text { of facade walls façade } \\
\text { without } \\
(\mathbf{k g} / \mathbf{m})\end{array}$ \\
\hline First, second, third & 2.9 & $202 \times 2.9 \times 0.7=410$ & $202 \times 2.9 \cong 586$ & $146 \times 2.9 \cong 425$ \\
shelter & 1 & 300 & 300 & 300 \\
\hline
\end{tabular}

Since the avarage load of equvalent extent of blades is less than 100 kilograms per square meter and the weight of blades per unit area is less than 40 kilograms per square meter, the minimum average of load of equivalent blade can instead of 100 kilograms per square meter, be 50 kilograms per square meter.

\subsection{Live loads}

Live loads are non-permanent load which is applied during the use or exploitation of buildings or other structures and are not includes the loads during construction or environmental loads such as wind load, snow and rain loads, flood and dead loads. Estimated values of such loads have been illustrated in Table 10.

Table 10. Live surface loads of different parts of the building

\begin{tabular}{cclc}
\hline Row & $\begin{array}{c}\text { Row in the table } \\
\text { Sixth issue }\end{array}$ & Application Type & Extensive Load $\left(\mathrm{Kg} / \mathrm{m}^{2}\right)$ \\
\hline 1 & $(1-1)$ & Conventional flat roofs & 150 \\
2 & $(3-3)$ & Stairs leading to the exit doors & 500 \\
4 & $(1-4)$ & (Rooms and other private areas (in residential buildings & 200 \\
\hline
\end{tabular}

\subsection{Seismic loading}

To analyze the buildings, the static analysis the regulation No 2800 is used. Relatively high earthquake risk area $(\mathrm{A}=0.3)$, land area of type three (III) and building importance coefficient equals $(\mathrm{I}=1)$. For calculation of the periodicity of buildings empirical correlations of Table 11 buildings in terms of regulation No. 2800 have been used. Also behavior coefficient of structures is intended according to Table 12. Structural importance coefficient is medium and percentage of contribution of the live load was equal to $20 \%$.

Table 11. Structure periodicity of for all types of buildings

\begin{tabular}{ll}
\hline Structure type & Periodicity of structure \\
\hline Construction steel moment frames & $\boldsymbol{T}=\mathbf{0 . 0 8 H ^ { \mathbf { 0 . 7 5 } }}$ \\
Other buildings & $\boldsymbol{T}=\mathbf{0 . 0 5} \boldsymbol{H}^{\mathbf{0 . 7 5}}$ \\
\hline
\end{tabular}


Table 12. Behavior coefficient of structure for different types of buildings

\begin{tabular}{ll} 
Lateral load-bearing system of building & Behavior coefficient \\
\hline Average Steel Moment Frames & $\mathbf{5}$ \\
Special CBF Braced & $\mathbf{5 . 5}$ \\
\hline
\end{tabular}

\section{Analysis and Design of Buildings}

In order to design the buildings according to the tenth issue of national Iranian building regulations the limited state resistance method is used. The combinations of intensified loads are also considered. The added resistance coefficient used in combination of intensified load is presented in Table 14:

Table 13. Regulations used in the analysis and design

\begin{tabular}{ll}
\hline Regulations & Utilizations \\
\hline Sixth issue of National Building Regulations & Regulations of loading \\
tenth issue National Building Regulations & Regulations of Design of steel buildings \\
AISC360-05/IBC2006 & Regulations used in ETABS \\
\hline
\end{tabular}

Table 14. Adding resistance coefficient for various structural systems

\begin{tabular}{ll}
\hline Lateral load-bearing seismic system type & $\Omega$ \\
\hline All Steel Moment Frames & 3 \\
All simple building frames with coax and cross-braced steel shaft & 2 \\
\hline
\end{tabular}

The control of structural deformation is executed according to combination of related loading to the allowable amounts of load in regulations. Shift control of building floors according to the Fourth Edition 2800 is as follows:

In buildings up to 5 floors: $\Delta_{a}=0.025 h$ and for other buildings: $\Delta_{a}=0.02 h$. in which $h$ is the height of the floor.

$$
\Delta_{a} \gg \Delta_{M}=c_{d} \Delta_{e u} \Leftrightarrow \Delta_{e u}<\frac{\Delta_{a}}{c_{d}},
$$

where $\Delta_{e u}$ is the relative lateral seismic shift of plan in each floor with the assumption of linearity behavior of structure which is obtained from structural analysis. $c_{d}$ is magnification ratio according to Table 15 based on the fourth edition of regulation No. 2800. In accordance with Rule (3-5-3) in the calculation of the relative shift of each floor, to comply with the above restrictions, the base shear value can be calculated by using the analyzing the periodicity of structure. This can reduce the earthquake forces and thus reduces the relative shift of the building.

Table 15. magnification coefficient for different types of lateral load-bearing systems

\begin{tabular}{ll}
\hline Load-bearing system type of building & Magnification Coefficient \\
\hline Average Steel Moment Frames & $\mathbf{4}$ \\
special CBF Braced steel & $\mathbf{5}$ \\
\hline
\end{tabular}

\subsection{Buildings under study}

Studied buildings in this paper consist of 9 buildings with steel frames and floors of three, five and ten. For steel buildings we considered three types of lateral load-bearing systems, including moment frameworks in both directions, bracing in both directions and moment frames and bracing in the other direction in the other direction. Those buildings specifications are presented in Table 16. 
Table 16. Buildings with steel frame

\begin{tabular}{ll}
\hline Row & Number of floors \\
\hline 1 & Three-storey building with lateral load-bearing system moment frame in both directions. \\
2 & Three-storey building with lateral load-bearing system bracing in both directions. \\
3 & Three-storey building with lateral load-bearing system moment frame in the direction of X and braced frame to Y \\
4 & Five-storey building with lateral bending frame in both directions. \\
\hline 5 & Babar five-storey building with a lateral load-bearing system bracing in both directions. \\
6 & Five-storey building with lateral load-bearing system moment frame in the direction of the X-braced frame to Y \\
7 & Ten-story building with lateral load-bearing system moment frames in both directions. \\
8 & Ten-story building with a lateral load-bearing system bracing in both directions. \\
9 & Ten-story building with 1 lateral load-bearing system moment frame in the direction of the X-braced frame to Y \\
\hline
\end{tabular}

\section{Analysis of buildings}

The weights of the different components of steel buildings are provided in Tables 17 and 18. Table 19 also compare the differences between the steel buildings with brick walls and blades (Table 17) and steel building with 3D PANEl walls (Table 18). Then the effect of various factors on the weight per unit of area of steel building structures will be discussed.

Table 17. The weight of different components of steel buildings with brick walls and blades

\begin{tabular}{lcccccc}
\hline Structure type & $\begin{array}{c}\text { Number of } \\
\text { floors }\end{array}$ & $\begin{array}{c}\text { Weight of } \\
\text { columns }(\mathrm{kg})\end{array}$ & $\begin{array}{c}\text { Weight of } \\
\text { beams }(\mathrm{kg})\end{array}$ & $\begin{array}{c}\text { Weight of } \\
\text { braces }(\mathrm{kg})\end{array}$ & $\begin{array}{c}\text { Total weight } \\
(\mathrm{kg})\end{array}$ & $\begin{array}{c}\text { Weight per unit of } \\
\text { surface }\left(\mathrm{kg} / \mathrm{m}^{2}\right)\end{array}$ \\
\hline Moment frames in both directions. & 3 & 11960.9 & 10802.2 & - & 22763.1 & 47.74 \\
Moment frames to X and bracing to & 3 & 8354.37 & 8161.85 & 2373.75 & 18890 & 39.6 \\
Bracing system in both directions. & 3 & 3521.62 & 8555.47 & 4647.4 & 16724.5 & 35.08 \\
Moment frames in both directions. & 5 & 32778.29 & 30205 & - & 62983.3 & 80.15 \\
Moment frames to X and bracing to & 5 & 19263 & 17971.25 & 4471 & 41705.31 & 53 \\
Bracing system in both directions. & 5 & 11961.7 & 12990.9 & 7745.6 & 32698.2 & 41.6 \\
Moment frames in both directions. & 10 & 90296.34 & 87083.93 & - & 177380.3 & 113.82 \\
Moment frames to X and bracing to Y & 10 & 61313 & 51814.4 & 10295.78 & 123423.1 & 79.2 \\
Bracing system in both directions. & 10 & 42495.6 & 27848.2 & 24701.8 & 95045.8 & 60.9 \\
\hline
\end{tabular}

Table 18. The weight of different components of steel buildings with 3D PANEL walls and blades made of drywall (light up)

\begin{tabular}{|c|c|c|c|c|c|c|}
\hline Structure type & $\begin{array}{l}\text { Number of } \\
\text { floors }\end{array}$ & $\begin{array}{l}\text { Weight of } \\
\text { columns }(\mathrm{kg})\end{array}$ & $\begin{array}{l}\text { Weight of } \\
\text { beams }(\mathrm{kg})\end{array}$ & $\begin{array}{l}\text { Weight of braces } \\
\text { (kg) }\end{array}$ & $\begin{array}{l}\text { Total weight } \\
(\mathrm{kg})\end{array}$ & $\begin{array}{l}\text { Weight per unit of } \\
\text { surface }\left(\mathrm{kg} / \mathrm{m}^{2}\right)\end{array}$ \\
\hline Moment frames in both directions & 3 & 11572.79 & 10685.67 & - & 22258.45 & 46.68 \\
\hline Moment frames to $\mathrm{X}$ and bracing to $\mathrm{Y}$ & 3 & 8138.9 & 8118.37 & 1143.93 & 17401.2 & 36.5 \\
\hline Bracing system in both directions. & 3 & 3365.6 & 8558.62 & 4647.34 & 16571.6 & 34.75 \\
\hline Moment frames in both directions. & 5 & 20987.43 & 25031.1 & - & 46018.52 & 58.56 \\
\hline Moment frames to $\mathrm{X}$ and bracing to $\mathrm{Y}$ & 5 & 16311.5 & 13629.35 & 4387.89 & 34328.7 & 43.68 \\
\hline Bracing system in both directions. & 5 & 7568.87 & 12187.3 & 7745.6 & 27502.79 & 35 \\
\hline Moment frames in both directions. & 10 & 63245.54 & 75884.8 & - & 139130.33 & 89.3 \\
\hline Moment frames to $\mathrm{X}$ and bracing to $\mathrm{Y}$ & 10 & 52078.8 & 41031.86 & 9912.1 & 103022.76 & 66.1 \\
\hline Bracing system in both directions. & 10 & 39312.9 & 22380.44 & 18066.4 & 79759.7 & 51.17 \\
\hline
\end{tabular}

Table 19. Differences in weight of steel buildings (Tables 17 and 18)

\begin{tabular}{llll}
\hline Structure type & $\begin{array}{l}\text { Number of } \\
\text { floors }\end{array}$ & $\begin{array}{l}\text { Total Difference in weight } \\
(\mathrm{kg})\end{array}$ & $\begin{array}{l}\text { Difference in weight of a unit as a } \\
\text { percentage }(\mathrm{kg} / \mathrm{m} 2)\end{array}$ \\
\hline Moment frames in both directions & 3 & 504.65 & 2.22 \\
Moment frames to X and bracing to $\mathrm{Y}$ & 3 & 1488.8 & 7.828 \\
Bracing system in both directions. & 3 & 152.9 & 0.941 \\
Moment frames in both directions. & 5 & 16964.78 & 26.937 \\
Moment frames to X and bracing to Y & 5 & 7376.61 & 17.585 \\
Bracing system in both directions. & 5 & 5195.41 & 15.865 \\
Moment frames in both directions. & 10 & 38249.97 & 21.543 \\
Moment frames to X and bracing to Y & 10 & 20400.34 & 16.54 \\
Bracing system in both directions. & 10 & 15286.1 & 16 \\
\hline
\end{tabular}

\subsection{Effect of Lateral load-bearing system}

As can be seen from the above Tables and graphs presented in Figs. 1 and 2, the overall weight per unit area of buildings with lateral load- bearing moment frame system in both directions, both for buildings (i.e. with brick walls and blades with 3D PANEL walls and drywall blades) is the highest and 
with the bracing system for buildings in both directions is the lowest values. It is due to that the moment frame system with fixed beam-column connections, causes beams involvement in withstanding earthquake loads and these forces increase the cross-beams in this system. Pillars also in the moment frame system are a part of lateral load-bearing system and according to their anchor and also transmitted beam anchor which is attached to them, needs more robust foundation than the other systems. On the other hand the load-bearing of moment frame is more sensitive than other systems for shifting and in some cases; side-shift control is decisive in choosing the appropriate sections. In buildings with a lateral load-bearing bracing system, connecting the beams to the pillars are of joint type. This type of connection causes the beams of each floor designable only for gravity loads and also no anchor (ideally) is transferred from the beams to the pillars. For this reason, beam and column sections in buildings with lateral loadbearing system is lighter than similar buildings with Lateral load-bearing of moment frame system. Naturally, the weight per unit area in buildings that has a moment frame buildings in the direction of $X$ and bracing for $\mathrm{Y}$, due to having features of both systems, have some weights between the buildings with lateral load-bearing of moment frame system in both directions and bracing in both directions.

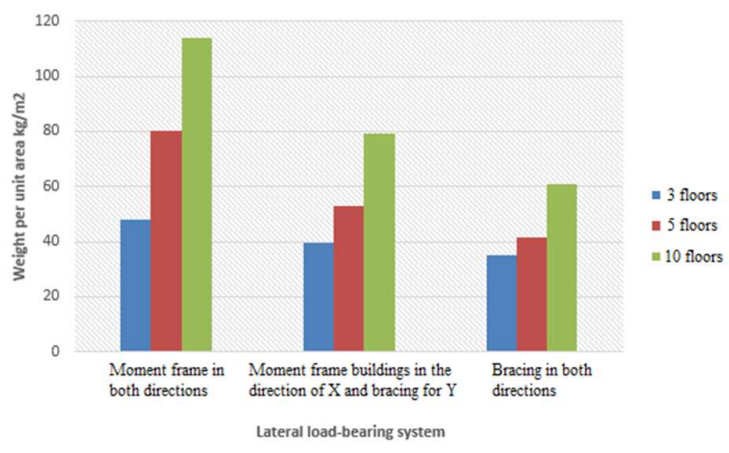

Fig. 1. Effect of lateral load-bearing system of weight per unit area on different floors of buildings with brick walls and blades

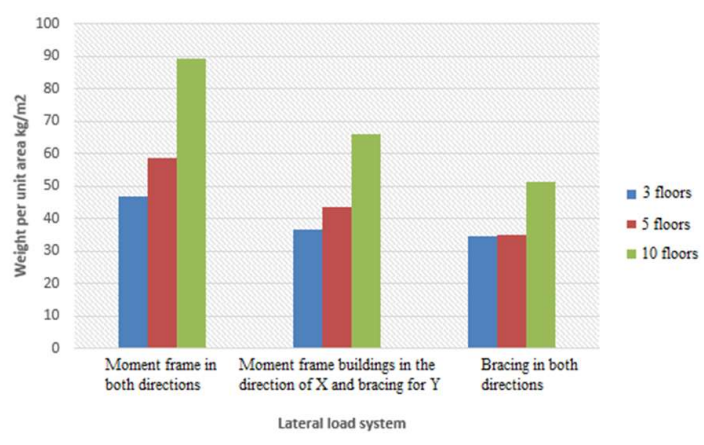

Fig. 2. Effect of lateral load-bearing system on weight per unit area of buildings with different floors and with 3D PANEL walls and blades made of drywall (light-up)

\subsection{The impact of the number of floors (increasing the height)}

In general, by increasing the number of floors in buildings, the total weight of the structures increase which results in increasing the earthquake forces and can change the distribution of the forces on the floors. This increasing in weight also increases the load gravity of pillars of the lower floors. Such factors will cause the weight of unit area of skeleton of the building increases by increasing the number of floors. The results in Figs. 3 to 5 also confirm the accuracy of the findings. According to this chart by increasing the number of floors, weight per unit area of buildings with different lateral load-bearing system is 
increased, both for buildings with brick walls and blades, also for buildings with 3D PANEL walls and drywall blades (light up).

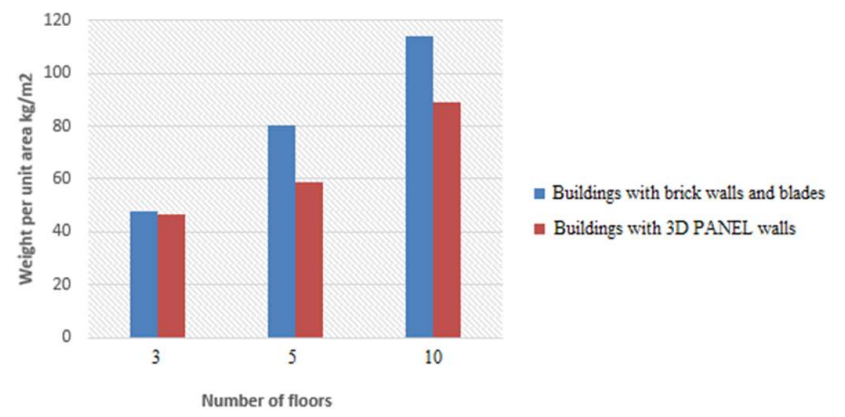

Fig. 3. The weight per unit area of buildings with lateral load-bearing with moment frame system in both directions with a number of different floors and loading

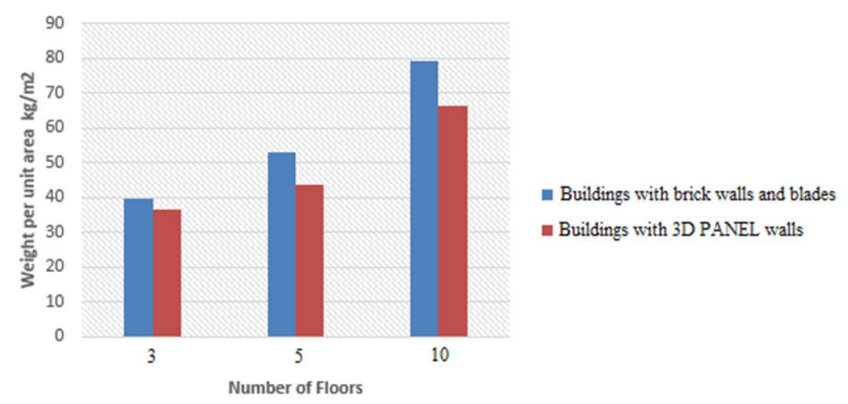

Fig. 4. The weight per unit area of buildings with lateral load-bearing with moment frames in direction to $\mathrm{X}$ and bracing to $\mathrm{Y}$, the number of floors and different loading

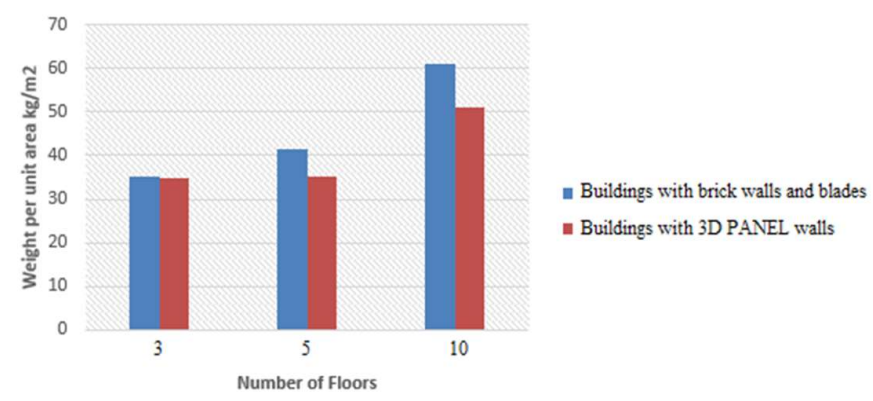

Fig. 5. The weight per unit area of buildings with lateral load-bearing with bracing system in both directions with a number of different classes and loading

\subsection{The impact of light weighting on the weight per unit area on building structure}

In general it is clear that with light weighting and using lightweight materials and industrialization, weight per unit area of buildings regardless of the number floors and type of the lateral load-bearing system, is reduced. But the remarkable thing in this article is using notes that the sixth issue of national regulations on the divider walls (blades) has mentioned. In this paper, drywall blades with single-layer wall have been replaced with W111 and weighing approximately $25 \mathrm{~kg} / \mathrm{m}^{2}$. As you know, in the floors that the live load is less than $500 \mathrm{~kg} / \mathrm{m}^{2}$, the average extent of equivalent load like blades should not be 
considered less than $100 \mathrm{~kg} / \mathrm{m}^{2}$ wide. In the buildings that light blades is used as sandwich walls, the minimum load can be reduced to $50 \mathrm{~kg} / \mathrm{m}^{2}$. Provided that the weight of one square meter of blades plus their attachments do not exceed of $40 \mathrm{~kg} / \mathrm{m}^{2}$. First impact of drywall gypsum boards walls can be set at the equivalent load of blades, so that equivalent load of blades for a conventional building is reduced to about 50 kilograms per square meter. According to Table 19 and Figs. (3-5), the use of short Light weighting for short buildings (three floors), weight per unit area of building for all kinds of systems the lateral loadbearing systems reduces to a very small amount. By increasing the number of floors so that the effect of light weighting is noticeable thus it is remarkable in the buildings of five and ten-storey skeleton structure the loss of weight. According to Table 19 in buildings with a bracing system in both directions, by increasing the number of floors, the rate of weight loss per unit area of the skeleton for the building of ten floors increases in comparison to the five-storey buildings with very low slope. The reason is that in this type of lateral load-bearing system the weight in all floors (Due to the joint connections) is independent of earthquake forces and increasing the height of the structure does not change the weight of the beams. Given that the number of elements in pillars and braces are usually less than the beams so with by increasing the height, total weight of structural skeleton is reduced less than the moment frame system.

\section{Conclusions}

In this paper, various effects of weight reduction of building components and lateral load-bearing systems on the weight per unit area of skeleton of steel buildings were examined and according to the analysis conducted on the results, the following points are noteworthy:

1. Generally in steel buildings by increasing the number of floors of the building the weight per unit area of building skeleton increases. This is an almost linear increasing.

2. In general for steel buildings of three floors, five floors and ten floors, the use of brace system in both directions of buildings, is resulted in the lowest weight per unit area of the building structure and thus it is the most optimal system between the investigated systems. Lateral load bearing moment frame system in one direction and the bracing in the other direction and moment frame system in both directions of buildings, respectively, are next in ranking.

3. Light weighting of steel structures for buildings of three floors, has a negligible impact on weight reduction of skeleton of the building per unit area. So it seems incremental cost of these systems is more than reduction of the cost of light weighting and the use of this system in normal buildings is not recommended. Of course, the impact of Light weighting of buildings will increase by increasing the number of floors, due to changes in the distribution of forces of the earthquake and building height, so Light weighting of tall buildings plays an important role in weight reduction of buildings.

4. Most effects of light weighting of steel building are observable in buildings with lateral loadbearing moment frame system and the least effect can be seen on buildings with bracings building in two directions.

\section{References}

Azizi-Bondarabadi, H., Mendes, N., Lourenço, P. B., \& Sadeghi, N. H. (2016). Empirical seismic vulnerability analysis for masonry buildings based on school buildings survey in Iran. Bulletin of Earthquake Engineering, 14(11), 3195-3229.

Bothara, J. K., Dizhur, D., \& Ingham, J. (2018, February). Masonry building design for earthquakeaffected remote areas of Nepal. In 10th Australasian Masonry Conference.

Dehghani, A., Nateghi-Alahi, F., \& Fischer, G. (2015). Engineered cementitious composites for strengthening masonry infilled reinforced concrete frames. Engineering Structures, 105, 197-208.

Duggal, S. K. (2007). Earthquake resistant design of structures. New Delhi: Oxford University Press. 
Ellingwood, B. R. (2001). Earthquake risk assessment of building structures. Reliability Engineering \& System Safety, 74(3), 251-262.

Gorman, J. R., Jaffe, S., \& Pruter, W. F. (1988). Plaster and Drywall Systems Manual. McGraw-Hill. 2010.

Hamidi Nezhad, J. \& Rezaei M. (2010). Comparison of the effect of light weighting of non-structural elements of building, on behavior, cost and speed of execution of various materials. International Conference on Light weighting and earthquake, Kerman.

Iranian National Building Code (2013). Part 6: loads on the building / the office of development and promotion of national building regulations (Ministry of Roads and Urban Development) - 2013 edition.

Iranian National Building Code, (2013). Part10: Design and Construction of Steel buildings / the office of development and promotion of national building regulations (Ministry of Roads and Urban Development) - 2013 Edition

Khatami, S.M. \& Tavoosi Tafreshi, Sh. (2010). The study of the effect of different types of metal frame on weight reduction of structures. International Conference on lightweight construction and earthquake, Kerman.

Mohammed, M. A., Yu, H., Furtado, A., Barbosa, A. R., Moaveni, B., Varum, H., ... \& Wood, R. L. (2017, July). Post-earthquake Field Measurement-Based System Identification and Finite Element Modeling of an 18-Story Masonry-Infilled RC Building. In International Conference on Experimental Vibration Analysis for Civil Engineering Structures (pp. 746-757). Springer, Cham.

Naghipour M \& Hatam, A. (2004). Reducing volume of building and its role in the economic structure of the plan on earthquake. The first National Congress of Civil Engineering, Sharif University of Technology, Tehran.

Park, J., Towashiraporn, P., Craig, J. I., \& Goodno, B. J. (2009). Seismic fragility analysis of low-rise unreinforced masonry structures. Engineering Structures, 31(1), 125-137.

Priestley, M. J. N., \& Seible, F. (1995). Design of seismic retrofit measures for concrete and masonry structures. Construction and Building Materials, 9(6), 365-377.

Priestley, M. J. N. (1986, January). Seismic design of concrete masonry shearwalls. In Journal Proceedings (Vol. 83, No. 1, pp. 58-68).

Rahimi Asl, M; Keyvani J \& Farzadi M. (2011). The effect of the architectural considerations on light weighting and reduction of seismic forces exerted on the building. International Conference on lightweight construction and earthquake. Iran, Kerman.

Sazedj, S., Morais, A. J., \& Jalali, S. (2017). Comparison of environmental benchmarks of masonry and concrete structure based on a building model. Construction and Building Materials, 141, 36-43.

Seyyed Kazemi, A, Ali beygi H.\& Esfandiari Fard M., (2010). Study of the effective solutions of weight reduction on reducing the weight of steel building structure. International Conference on lightweight construction and earthquake, Kerman.

Šipoš, T. K., Rodrigues, H., \& Grubišić, M. (2018). Simple design of masonry infilled reinforced concrete frames for earthquake resistance. Engineering Structures, 171, 961-981.

Uang, C. M. (1991). Establishing R (or R w) and C d factors for building seismic provisions. Journal of structural Engineering, 117(1), 19-28.

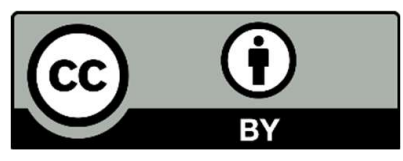

(C) 2019 by the authors; licensee Growing Science, Canada. This is an open access article distributed under the terms and conditions of the Creative Commons Attribution (CC-BY) license (http://creativecommons.org/licenses/by/4.0/). 